\title{
Successful Treatment with Atomoxetine of an Adolescent Boy with Attention Deficit/ Hyperactivity Disorder, Extreme Obesity, and Reduced Melanocortin 4 Receptor Function
}

\author{
Wilfried Pott ${ }^{a}$ Özgür Albayrak ${ }^{b} \quad$ Anke Hinney $^{\mathrm{b}} \quad$ Johannes Hebebrand $^{\mathrm{b}}$ \\ Ursula Pauli-Pott ${ }^{\mathrm{a}}$ \\ ${ }^{a}$ Department of Child and Adolescent Psychiatry, Psychosomatics and Psychotherapy,

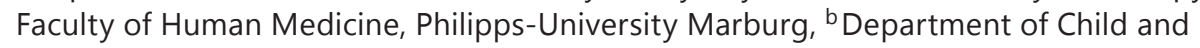 \\ Adolescent Psychiatry, University of Duisburg-Essen, Essen, Germany
}

\section{Key Words}

Pharmacogenetics · Brain-derived neurotrophic factor - Weight loss · Appetite control ·

Methylphenidate

\section{Abstract}

Objective: Recent case reports suggest a link between reduced melanocortinergic tone and both obesity and attention deficit / hyperactivity disorder (ADHD). We present the case of a 13-year-old, male, obese MC4R mutation carrier with ADHD. Case Report: The boy carries a heterozygous mutation in the melanocortin 4 receptor gene (MC4R; Met281Val), that leads to a reduced receptor function. Dominant mutations of this type represent major gene effects for obesity. He participated in a lifestyle intervention program for obesity and received treatment with the selective norepinephrine re-uptake inhibitor atomoxetine for 31 months. The boy markedly reduced his BMI from 47.2 to $29.6 \mathrm{~kg} / \mathrm{m}^{2}$. Conclusion: Atomoxetine proved to efficiently reduce weight in a severely obese MC4R mutation carrier with ADHD. We briefly discuss possible mechanisms for our observation, including evidence for the functional connectivity between melanocortinergic, dopaminergic, and norepinephrinergic brain circuitries.

Copyright (c) 2013 S. Karger GmbH, Freiburg

\section{Introduction}

Recent case reports suggest a link between reduced melanocortinergic tone and both obesity and attention deficit / hyperactivity disorder (ADHD). We present the case of an obese 13-year-old maleMC4R mutation carrier with ADHD. 
Pott et al.: Successful Treatment with Atomoxetine of an Adolescent Boy with Attention Deficit/Hyperactivity Disorder, Extreme Obesity, and Reduced Melanocortin ...

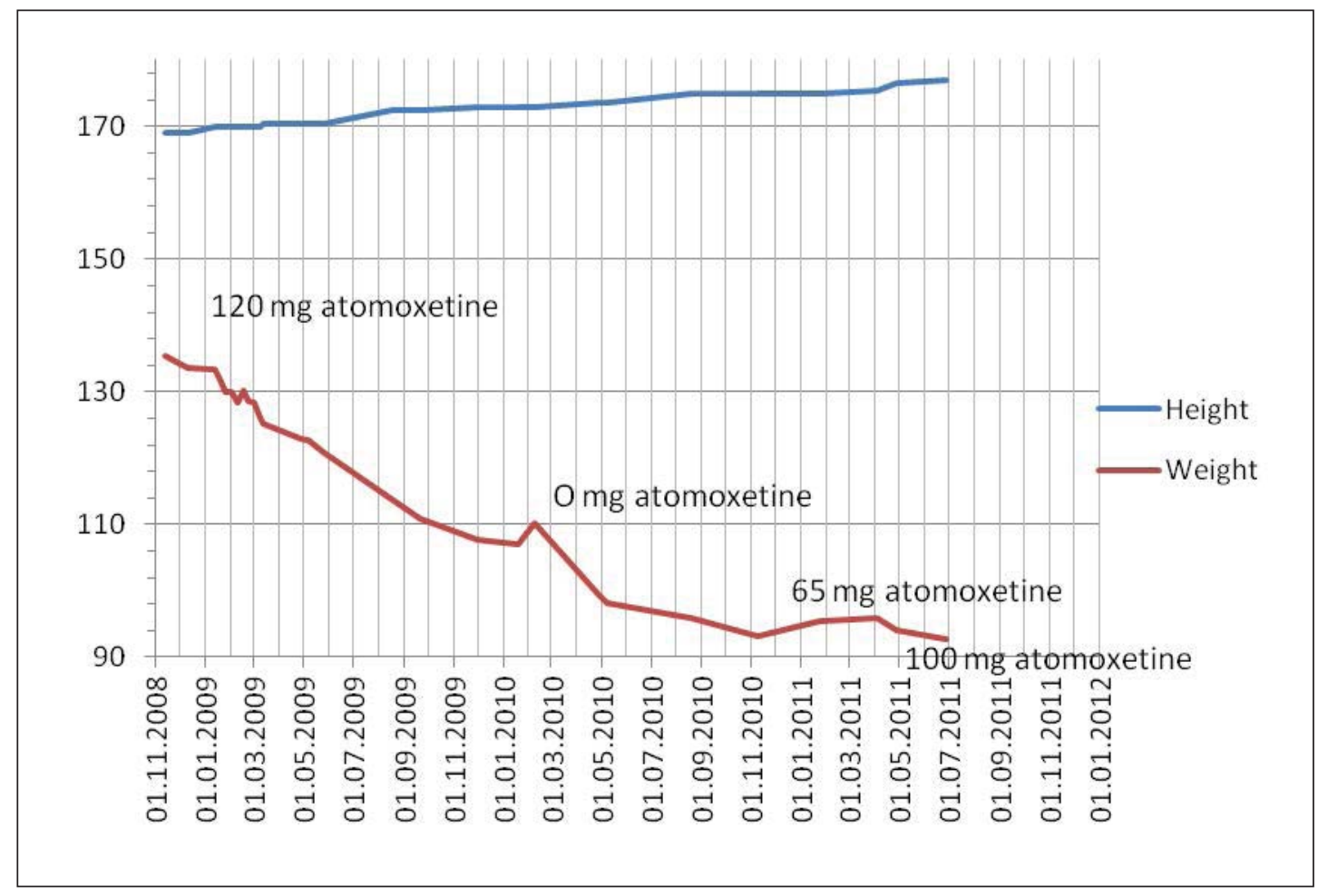

Fig. 1. Development of weight in relation to atomoxetine daily dose.

\section{Case Report}

The 13-year- and 11-month-old male index patient was referred to our hospital by his general practitioner for treatment of his extreme obesity. At time of referral, he had a BMI of $47.4 \mathrm{~kg} / \mathrm{m}^{2}$ corresponding to a BMI standard deviation score (BMI-SDS) of 3.44 [1] (fig. 1).

Several family members were also overweight/obese (BMI mother $39.42 \mathrm{~kg} / \mathrm{m}^{2}$; BMI father 29.22 $\mathrm{kg} / \mathrm{m}^{2}$; BMI sister (8 years and 2 months old) $28.1 \mathrm{~kg} / \mathrm{m}^{2}$, BMI-SDS 2.72). The brother was 11 years and 3 months old and of normal weight (BMI $18.7 \mathrm{~kg} / \mathrm{m}^{2}$, BMI-SDS 0.32).

Upon referral to our child and adolescent psychiatric service, he was in a dysphoric state of mood, revealed signs of inattention, and was easily distractible. According to his parents and his teachers he was inattentive, but not hyperactive. His school performance was below average. He experienced frequent bullying at school and reported being physically abused at school, which he claimed made him feel anxious and nervous. His eating pattern had been abnormal since early childhood. Most of his food intake was between mealtimes. He got hungry soon after having finished a meal. He initially became obese as a toddler.

Physical examination revealed acanthosis nigricans in the neck, striae distensae, and Tanner stage 2. Total cholesterol was $241 \mathrm{mg} / \mathrm{dl}$, HDL-cholesterol $46 \mathrm{mg} / \mathrm{dl}$, and LDL-cholesterol $179 \mathrm{mg} / \mathrm{dl}$; the oral glucose tolerance test showed a borderline value at $139 \mathrm{mg} / \mathrm{dl}$ after $2 \mathrm{~h}$. The electrocardiogram on admission showed a subtotal right bundle branch block, and 24-hour blood pressure examination revealed an arterial hypertension. $90 \%$ of the measurements were above the 95th age-related percentile, pulse frequency varied between 50 and 80 beats $/ \mathrm{min}$.

A mutation screen of the $M C 4 R$ (for details see [2,3]) revealed heterozygosity for Met281Val of both the index patient and his mother. The same mutation was also detected heterozygously in his 7-year-old sister. She also showed symptoms of inattention but no hyperactivity. The brother carried the wild type.

The Met281Val mutation has been shown to result in a reduced cell surface expression of the receptor and in slightly increased EC50 levels of $\alpha$-melanocyte-stimulating-hormone ( $\alpha$-MSH) in comparison to the wild-type receptor [4], thus entailing a partial loss-of-function. 
Pott et al.: Successful Treatment with Atomoxetine of an Adolescent Boy with Attention Deficit/Hyperactivity Disorder, Extreme Obesity, and Reduced Melanocortin ...

Clinical psychiatric assessment by an experienced child and adolescent psychiatrist on the basis of a structured interview with the parents and the child in succession (Schedule for Affective Disorders and Schizophrenia for School-Age Children - Present and Lifetime version (K-SADS-PL), Version 1.0 [5]) and the clinical impression obtained by reports from therapists and teachers of the hospital and school, respectively, revealed that the index patient fulfilled diagnostic criteria for the inattentive subtype of ADHD according to the DSM-IV TR criteria [6]. The diagnosis was further underscored by neuropsychological assessments comprising subtests on inhibitory control (go / no go, incompatibility) of the Test Battery on Attentional Performance (TAP) [7] and the d2 cancellation test [8].

His intelligence level was within the normal range (IQ 95; Culture Fair Test (CFT 20) [9]). The index patient also fulfilled the DSM-IV TR research criteria [6] for binge eating disorder (BED) based on the results of a structured psychiatric interview with the mother and the adolescent (interview version of the Questionnaire on Eating and Weight Pattern (QEWP) by [10]).

\section{Treatment}

At the age of 11, the boy took part in a 10-week inpatient weight reduction program during which he lost $13 \mathrm{~kg}$. Back at home, he gained $38 \mathrm{~kg}$ in the following 6 months. At the current referral for renewed inpatient treatment, his weight was $135.5 \mathrm{~kg}$, his height measured $169 \mathrm{~cm}$ (BMI $47.4 \mathrm{~kg} / \mathrm{m}^{2}$, BMI-SDS 3.44). He started with a diet of 1,600 kcal/day; physical exercise was promoted. He lost 1-1.5 kg/week; however, during weekend holidays at home he suffered from binge eating episodes, and his weight increased between 1 and $3 \mathrm{~kg}$ during each weekend. The patient subjectively attributed his initiation of eating to a high arousal level and feelings of internal agitation associated with a loss of control over eating. He consumed up to $4 \mathrm{l}$ of caffeinated, sugary softdrinks over a day.

In light of our clinical findings and the delineated difficulties of losing weight, we decided to initiate treatment with the selective noradrenergic re-uptake inhibitor atomoxetine during week 3 of inpatient treatment. The dose was increased stepwise to $120 \mathrm{mg} /$ day. Inattention improved; in the attention test (d2 Test of Attention) he scored in the normal range (54rd percentile) after treatment for 3 weeks. The incompatibility standard deviation reaction time (T-scores) of the TAP indicated an improvement ranging from 42 at no dose to 54 at a dose of $120 \mathrm{mg} /$ day atomoxetine.

After 8 weeks of inpatient treatment, he was referred to our outpatient lifestyle intervention weight reduction group program for overweight and obese children (FitKds) [11-13]. The BMI at discharge was 42.9 $\mathrm{kg} / \mathrm{m}^{2}$. He now was able to monitor and control his daily caloric intake, and his school performance improved substantially. During the first 6 months of this outpatient program his weight steadily decreased to a BMI of $36.0 \mathrm{~kg} / \mathrm{m}^{2}$ (BMI-SDS 2.86).

The boy showed good compliance to the lifestyle intervention and also a significant improvement of attentional and learning problems. Therefore, we reduced atomoxetine dosage for 3 months and then completely discontinued the medication while the boy continued to take part in the lifestyle intervention. Three weeks after having stopped the medication the patient showed a weight gain ( $3 \mathrm{~kg}$ ) for the first time in the observed period, although he reported a daily intake of 1,400 calories (fig. 1). Inattention worsened; in the TAP he scored 42 (reaction time). We thus began to treat him with atomoxetine again. Body weight again decreased rapidly (fig. 1). After 12 months, at the end of the program, his BMI was $33.1 \mathrm{~kg} / \mathrm{m}^{2}$ (BMI-SDS 2.59). Six months after having finished the lifestyle intervention and under continuous medication, his BMI was $30.4 \mathrm{~kg} / \mathrm{m}^{2}$ (BMI-SDS 2.25). At this time, he showed elevated pulse frequency, whereas blood pressure improved. He received no pharmacological antihypertensive treatment. Consequently, we reduced atomoxetine for a second time, which was followed by a slight increase in body weight (BMI $31.2 \mathrm{~kg} / \mathrm{m}^{2}$; BMI-SDS 2.35) and a decrease of pulse frequency. Two months later, the atomoxetine dosage was elevated to $100 \mathrm{mg} /$ day, and consequently his weight decreased again (BMI $29.6 \mathrm{~kg} / \mathrm{m}^{2}$; BMI-SDS 2.11), whereas pulse frequency increased.

\section{Discussion}

This is the second case report on substantial weight reduction upon treatment with ADHD medication in a child with early onset extreme obesity due to reduced MC4R function and comorbid ADHD. In the previous case study [14] the MC4R mutation was at a different position (Glu308Lys; [15]) but also resulted in a reduced receptor function - thus the func- 
Pott et al.: Successful Treatment with Atomoxetine of an Adolescent Boy with Attention Deficit/Hyperactivity Disorder, Extreme Obesity, and Reduced Melanocortin ...

tional implications of both mutations is similar. In the first patient methylphenidate was used in contrast to the use of atomoxetine in the present study. Although methylphenidate is pharmacodynamically different from atomoxetine, the mechanisms that beneficially resulted in such a massive weight loss and amelioration of ADHD symptoms might be similar to our case and have been extensively discussed [14]. Potentially, the reduced melanocortinergic tone due to reduced melanocortin MC4R activity specifically contributes to symptoms of inattention and to excessive weight gain in thus predisposed individuals, which are both ameliorated by atomoxetine or the stimulant methylphenidate.

A growing number of clinical and epidemiological studies suggest a link between ADHD and obesity in children, adolescents, and adults [16-20]. Vice versa, obesity is associated with ADHD in subjects of all ages [21-36] in both clinical and epidemiological samples. However, the evidence for the association of ADHD and obesity is not completely consistent [37-39]. It has been hypothesized, that, at least in part, disturbances in eating behavior, such as impulsive binge eating and eating in response to external rewarding cues caused by reward deficiency and/or low inhibitory control capacity, mediate the association between ADHD and obesity $[12,16,40]$.

About $2 \%$ of extremely obese German children heterozygously harbor MC4R [2]. Single reports have linked $M C 4 R$ deficiency with ADHD $([14,41]$, current study). Based on these case reports the co-occurrence of ADHD and obesity might be related to the reduced melanocortinergic tone of $M C 4 R$ mutation carriers. Further studies are warranted to assess the strength of the association to ADHD; we identify ADHD in a subgroup of mutation carriers only (personal observation). The beneficial effect of atomoxetine or methylphenidate [14] on both ADHD and obesity could be related to the improvement of attention deficit and impulse control, which in turn may have helped to improve BED symptoms, thus resulting in substantial weight loss. Indeed, a reduced impulse control may constitute a neuropsychological link between obesity and BED [11, 12]. In obese individuals, lack of impulse control entails a reduced ability to resist palatable foods $[42,43]$. In overweight youths, the amount of overweight is negatively correlated with neuropsychological impulse control performance [11]. It has been shown that the presentation of high-caloric food pictures to obese individuals leads to striatal and frontal activation $[44,45]$. Other studies also showed reduced activity in prefrontal regions, which are involved in the development of adephagia [46]. Probably, the neurophysiological basis is a deviation of the frontostriatal dopamine-modulated network [43, 47]. While MC4R-null mice are hyperphagic and obese, they exhibit impairments in acquisition of operant responding for a high fat reinforcement. Restoration of MC4R signaling in D1R neurons normalizes procedural learning without affecting motivation to obtain high-fat diet [48].

Atomoxetine, which is a second line pharmacological treatment option in ADHD, selectively inhibits noradrenergic re-uptake $[49,50]$. Adults with reduced MC4R function show a lowered adrenergic level, a decreased pulse rate [51], and a reduced systolic and diastolic blood pressure and catecholamine elimination in the urine [52]. The extensive consumption of caffeine reported by the index patient prior to beginning the medication might be interpreted as a kind of self-stimulation of his central sympathetic system. Indeed, our patient reduced caffeine intake significantly during the course of stimulant treatment. Norepinephrine can stimulate the sympathetic nervous system, resulting in an elevated modified basic metabolic rate; in our patient pulse frequency was intermittently well above average, leading to intermittent cessation of treatment. Single studies of obese adults with comorbid ADHD have shown a significant weight reduction during medical treatment with atomoxetine $[53,54]$. These changes were not as dramatic as in our patient. We therefore hypothesize that the main reason for this strong weight loss is related to the reduced MC4R function. Elevation of noradrenergic levels due to atomoxetine might therefore be beneficial in conditions associated with a low noradrenergic/sympathetic tone. 
Pott et al.: Successful Treatment with Atomoxetine of an Adolescent Boy with Attention Deficit/Hyperactivity Disorder, Extreme Obesity, and Reduced Melanocortin ...

To conclude, our case report underlines the assumption that a reduced melanocortinergic tone and ADHD symptomatology might result from possible common mechanisms, involving the dopaminergic, noradrenergic, and sympathetic nervous system. A psychopharmacological intervention that affects these systems might have therefore a beneficial effect for this subgroup of obese individuals. However, before generalizing this treatment, it should be taken into account that atomoxetine may provoke cardiovascular side effects, as seen in our patient. Because of these side effects, treatment with atomoxetine has to be carefully monitored. Future research is warranted to determine if the weight-reducing effect of atomoxetine and stimulants result from the beneficial effects on ADHD symptoms which in turn lead to an improved eating behavior or if, alternatively, the weight loss is due to an increased sympathetic tone. Both mechanisms may prove to be relevant in one and the same individual.

\section{Acknowledgment}

This work was supported by grants from the Bundesministerium für Bildung und Forschung (01KU0903 and NGFNplus 01GS0820), from the German Research Association (DFG; He1446/9-1) and from the European Community's Seventh Framework Programme (FP7/2007-2013) under grant agreement no. 245009.

\section{Disclosure Statement}

The authors declare that they have no conflict of interest.

\section{References}

1 Kromeyer-Hauschild K, Wabitsch M, Kunze D, Geller D, Geiss H.C, Hesse V, von Hippel A, Jaeger U, Johnsen D, Korte W, Menner K, Muller G, Muller JM, Niemann-Pilatus A, Remer T, Schaefer F, Wittchen HU, Zabransky S, Zellner K, Ziegler A, Hebebrand J: Percentiles of body mass index in children and adolescents evaluated from different regional German studies. Monatsschr Kinderheilkd 2001;149:807-818

- 2 Hinney A, Hohmann S, Geller F, Vogel C, Hess C, Wermter AK, Brokamp B, Goldschmidt H, Siegfried W, Remschmidt H, Schafer H, Gudermann T, Hebebrand J: Melanocortin-4 receptor gene: case-control study and transmission disequilibrium test confirm that functionally relevant mutations are compatible with a major gene effect for extreme obesity. J Clin Endocrinol Metab 2003;88:4258-4267.

3 Hinney A, Bettecken T, Tarnow P, Brumm H, Reichwald K, Lichtner P, Scherag A, Nguyen TT, Schlumberger P, Rief W, Vollmert C, Illig T, Wichmann HE, Schafer H, Platzer M, Biebermann H, Meitinger T, Hebebrand J: Prevalence, spectrum, and functional characterization of melanocortin-4 receptor gene mutations in a representative population-based sample and obese adults from Germany. J Clin Endocrinol Metab 2006;91:17611769.

4 Reinehr T, Hebebrand J, Friedel S, Toschke AM, Brumm H, Biebermann H, Hinney A: Lifestyle intervention in obese children with variations in the melanocortin 4 receptor gene. Obesity (Silver Spring) 2009;17:382-389.

5 Kaufman J, Birmaher B, Brent D, Rao U, Flynn C, Moreci P, Williamson D, Ryan N: Schedule for Affective Disorders and Schizophrenia for School-Age Children-Present and Lifetime Version (K-SADS-PL): initial reliability and validity data. J Am Acad Child Adolesc Psychiatry 1997;36:980-988.

6 American Psychiatric Association: Manual of Mental Disorders - DSM-IV-TR. Washington, D.C., American Psychiatric Association, 2000.

7 Zimmermann P, Fimm B: Testbatterie zur Aufmerksamkeitsprüfung. Psytest, 2012. www.psytest.net/index. php?page $=$ TAP $-2-2$.

8 Brickenkamp R: Test d2 - Aufmerksamkeits-Belastungs-Test. Handanweisung. Göttingen, Hogrefe, 2002.

9 Weiß RH: Grundintelligenztest Skala 2 (CFT 20) mit Wortschatztest (WS) und Zahlenfolgentest (ZF). Handanweisung,4, überarbeitete Auflage. Göttingen, Westermann Test, 1998.

10 Johnson WG, Kirk AA, Reed AE: Adolescent version of the questionnaire of eating and weight patterns: reliability and gender differences. Int J Eat Disord 2001;29:94-96.

11 Pauli-Pott U, Albayrak 0, Hebebrand J, Pott W: Does inhibitory control capacity in overweight and obese children and adolescents predict success in a weight-reduction program? Eur Child Adolesc Psychiatry 2010; 19:135-141. 
Pott et al.: Successful Treatment with Atomoxetine of an Adolescent Boy with Attention Deficit/Hyperactivity Disorder, Extreme Obesity, and Reduced Melanocortin ...

12 Pauli-Pott U, Albayrak 0, Hebebrand J, Pott W: Association between inhibitory control capacity and body weight in overweight and obese children and adolescents: dependence on age and inhibitory control component. Child Neuropsychol 2010;16:592-603.

13 Summerbell CD, Ashton V, Campbell KJ, Edmunds L, Kelly S, Waters E: Interventions for treating obesity in children. Cochrane Database Syst Rev 2003;3:CD001872.

14 Albayrak O, Albrecht B, Scherag S, Barth N, Hinney A, Hebebrand J: Successful methylphenidate treatment of early onset extreme obesity in a child with a melanocortin-4 receptor gene mutation and attention deficit/ hyperactivity disorder. Eur J Pharmacol 2011;660:165-170.

-15 Santini F, Maffei M, Ceccarini G, Pelosini C, Scartabelli G, Rosellini V, Chiellini C, Marsili A, Lisi S, Tonacchera M, Agretti P, Chiovato L, Mammoli C, Vitti P, Pinchera A: Genetic screening for melanocortin-4 receptor mutations in a cohort of Italian obese patients: description and functional characterization of a novel mutation. J Clin Endocrinol Metab 2004;89:904-908.

16 Cortese S, Vincenzi B: Obesity and ADHD: clinical and neurobiological implications. Curr Top Behav Neurosci 2012;9:199-218.

-17 Agranat-Meged AN, Deitcher C, Goldzweig G, Leibenson L, Stein M, Galili-Weisstub E: Childhood obesity and attention deficit/hyperactivity disorder: a newly described comorbidity in obese hospitalized children. Int J Eat Disord 2005;37:357-359.

18 Erermis S, Cetin N, Tamar M, Bukusoglu N, Akdeniz F, Goksen D: Is obesity a risk factor for psychopathology among adolescents? Pediatr Int 2004;46:296-301.

19 Altfas JR: Prevalence of attention deficit/hyperactivity disorder among adults in obesity treatment. BMC Psychiatry 2002;2:9.

20 Fleming JP, Levy LD, Levitan RD: Symptoms of attention deficit hyperactivity disorder in severely obese women. Eat Weight Disord 2002;10:e10-13.

-21 Biederman J, Faraone SV, Monuteaux MC, Plunkett EA, Gifford J, Spencer T: Growth deficits and attentiondeficit/hyperactivity disorder revisited: impact of gender, development, and treatment. Pediatrics 2003;111: 1010-1016.

-22 Curtin C, Bandini LG, Perrin EC, Tybor DJ, Must A: Prevalence of overweight in children and adolescents with attention deficit hyperactivity disorder and autism spectrum disorders: a chart review. BMC Pediatr 2005;5:48.

23 Faraone SV, Biederman J, Monuteaux M, Spencer T: Long-term effects of extended-release mixed amphetamine salts treatment of attention-deficit/hyperactivity disorder on growth. J Child Adolesc Psychopharmacol 2005;15:191-202.

24 Holtkamp K, Konrad K, Müller B, Heussen N, Herpertz S, Herpertz-Dahlmann B, Hebebrand J: Overweight and obesity in children with attention-deficit/hyperactivity disorder. Int J Obes (Lond) 2004;28:685-689.

25 Hubel R, Jass J, Marcus A, Laessle RG: Overweight and basal metabolic rate in boys with attention-deficit/ hyperactivity disorder. Eat Weight Disord 2006;11:139-146.

26 Ptacek R, Kuzelova H, Paclt I, Zukov I, Fischer S: Anthropometric changes in non-medicated ADHD boys. Neuro Endocrinol Lett 2009;30:377-381.

27 Spencer TJ, Biederman J, Harding M, O’Donnell D, Faraone SV, Wilens TE: Growth deficits in ADHD children revisited: evidence for disorder-associated growth delays? J Am Acad Child Adolesc Psychiatry 1996;35: 1460-1469.

28 Swanson J, Greenhill L, Wigal T, Kollins S, Stehli A, Davies M, Chuang S, Vitiello B, Skrobala A, Posner K, Abikoff H, Oatis M, McCracken J, McGough J, Riddle M, Ghuman J, Cunningham C, Wigal S: Stimulant-related reductions of growth rates in the PATS. J Am Acad Child Adolesc Psychiatry 2006;45:1304-1313.

29 Anderson SE, Cohen P, Naumova EN, Must A: Relationship of childhood behavior disorders to weight gain from childhood into adulthood. Ambul Pediatr 2006;6:297-301.

-30 Chen AY, Kim SE, Houtrow AJ, Newacheck PW: Prevalence of obesity among children with chronic conditions. Obesity (Silver Spring) 2010;18:210-213.

-31 Erhart M, Herpertz-Dahlmann B, Wille N, Sawitzky-Rose B, Holling H, Ravens-Sieberer U: Examining the relationship between attention-deficit/hyperactivity disorder and overweight in children and adolescents. Eur Child Adolesc Psychiatry 2012;21:39-49.

-32 Lam LT, Yang L: Overweight/obesity and attention deficit and hyperactivity disorder tendency among adolescents in China. Int J Obes (Lond) 2007;31:584-590.

-33 Fuemmeler BF, Ostbye T, Yang C, McClernon FJ, Kollins SH: Association between attention-deficit/hyperactivity disorder symptoms and obesity and hypertension in early adulthood: a population-based study. Int J Obes (Lond) 2011;35:852-862.

-34 Waring E, Lapane KL: Overweight in children and adolescents in relation to attention-deficit/hyperactivity disorder: results from a national sample. Pediatrics 2008;122:e1-e6.

-35 de Zwaan M, Gruss B, Muller A, Philipsen A, Graap H, Martin A, Glaesmer H, Hilbert A: Association between obesity and adult attention-deficit/hyperactivity disorder in a German community-based sample. Obes Facts 2011;4:204-211.

-36 Pagoto SL, Curtin C, Lemon SC, Bandini LG, Schneider KL, Bodenlos JS, Ma Y: Association between adult attention deficit/hyperactivity disorder and obesity in the US population. Obesity (Silver Spring) 2009;17: 539-544.

37 Braet C, Claus L, Verbeken S, Van Vlierberghe L: Impulsivity in overweight children. Eur Child Adolesc Psychiatry 2007;16:473-483. 
Pott et al.: Successful Treatment with Atomoxetine of an Adolescent Boy with Attention Deficit/Hyperactivity Disorder, Extreme Obesity, and Reduced Melanocortin ...

-38 Mustillo S, Worthman C, Erkanli A, Keeler G, Angold A, Costello EJ: Obesity and psychiatric disorder: developmental trajectories. Pediatrics 2003;111:851-859.

-39 Dubnov-Raz G, Perry A, Berger I: Body mass index of children with attention-deficit/hyperactivity disorder. J Child Neurol 2011;26:302-308.

-40 Cortese S, Isnard P, Frelut ML, Michel G, Quantin L, Guedeney A, Falissard B, Acquaviva E, Dalla Bernardina B, Mouren MC: Association between symptoms of attention-deficit/hyperactivity disorder and bulimic behaviors in a clinical sample of severely obese adolescents. Int J Obes (Lond) 2007;31:340-346.

-41 Agranat-Meged A, Ghanadri Y, Eisenberg I, Ben Neriah Z, Kieselstein-Gross E, Mitrani-Rosenbaum S: Attention deficit hyperactivity disorder in obese melanocortin-4-receptor (MC4R) deficient subjects: A newly described expression of MC4R deficiency. Am J Med Genet B Neuropsychiatr Genet 2008;147B:1547-1553.

42 Davis C, Levitan RD, Smith M, Tweed S, Curtis C: Associations among overeating, overweight, and attention deficit/hyperactivity disorder: a structural equation modelling approach. Eating Behaviors 2006;7:266-274.

-43 Appelhans BM: Neurobehavioral inhibition of reward-driven feeding: implications for dieting and obesity. Obesity (Silver Spring) 2009;17:640-647.

44 Rothemund Y, Preuschhof C, Bohner G, Bauknecht HC, Klingebiel R, Flor H, Klapp BF: Differential activation of the dorsal striatum by high-calorie visual food stimuli in obese individuals. Neuroimage 2007;37:410-421.

-45 Stoeckel LE, Weller RE, Cook EW 3rd, Twieg DB, Knowlton RC, Cox JE: Widespread reward-system activation in obese women in response to pictures of high-calorie foods. Neuroimage 2008;41:636-647.

46 Volkow ND, Wang GJ, Telang F, Fowler JS, Thanos PK, Logan J, Alexoff D, Ding YS, Wong C, Ma Y, Pradhan K: Low dopamine striatal D2 receptors are associated with prefrontal metabolism in obese subjects: possible contributing factors. Neuroimage 2008;42:1537-1543.

47 Cortese S, Angriman M, Maffeis C, Isnard P, Konofal E, Lecendreux M, Purper-Ouakil D, Vincenzi B, Bernardina BD, Mouren MC: Attention-deficit/hyperactivity disorder (ADHD) and obesity: a systematic review of the literature. Crit Rev Food Sci Nutr 2008;48:524-537.

-48 Cui H, Mason BL, Lee C, Nishi A, Elmquist JK, Lutter M: Melanocortin 4 receptor signaling in dopamine 1 receptor neurons is required for procedural memory learning. Physiol Behav 2012;106:201-210.

49 Garnock-Jones KP, Keating GM: Atomoxetine: a review of its use in attention-deficit hyperactivity disorder in children and adolescents. Paediatr Drugs 2009;11:203-226.

50 Michelson D, Faries D, Wernicke J, Kelsey D, Kendrick K, Sallee FR, Spencer T: Atomoxetine in the treatment of children and adolescents with attention-deficit/hyperactivity disorder: a randomized, placebo-controlled, dose-response study. Pediatrics 2001;108:E83.

-51 Sayk F, Heutling D, Dodt C, Iwen KA, Wellhoner JP, Scherag S, Hinney A, Hebebrand J, Lehnert H: Sympathetic function in human carriers of melanocortin-4 receptor gene mutations. J Clin Endocrinol Metab 2010;95: 1998-2002.

-52 Greenfield JR, Miller JW, Keogh JM, Henning E, Satterwhite JH, Cameron GS, Astruc B, Mayer JP, Brage S, See TC, Lomas DJ, O’Rahilly S, Farooqi IS: Modulation of blood pressure by central melanocortinergic pathways. N Engl J Med 2009;360:44-52.

53 Gadde KM, Yonish GM, Wagner HR Jr, Foust MS, Allison DB: Atomoxetine for weight reduction in obese women: a preliminary randomised controlled trial. Int J Obes (Lond) 2006;30:1138-1142.

54 McElroy SL, Guerdjikova A, Kotwal R, Welge JA, Nelson EB, Lake KA, Keck PE Jr, Hudson JI: Atomoxetine in the treatment of binge-eating disorder: a randomized placebo-controlled trial. J Clin Psychiatry 2007;68:390398. 